\title{
TINGKAT KESUKAAN KONSUMEN TERHADAP IKAN CAKALANG (Katsuwonus pelamis L.) ASAP YANG DIRENDAM DALAM EKSTRAK KULIT MANGGIS
}

\author{
Abdala Y. Bulele ${ }^{1}$, Jenki Pongoh ${ }^{2}$ dan Albert R. Reo $^{2}$ \\ ${ }^{1)}$ Mahasiswa pada Program Studi Teknologi Hasil Perikanan FPIK Unsrat Manado \\ ${ }^{2)}$ Staf pengajar pada Program Studi Teknologi Hasil Perikanan FPIK Unsrat Manado \\ Email: abdalabulele@yahoo.com.
}

\begin{abstract}
Metode pengasapan yang sering dilakukan oleh masyarakat adalah pengasapan panas yaitu pengasapan dengan menggunakan suhu tinggi mencapai $100^{\circ} \mathrm{C}$ bahkan $120^{\circ} \mathrm{C}$ dengan cara meletakkan ikan yang akan diasapi langsung di atas sumber panas, sehingga kontak langsung antara partikel asap dan ikan sangat besar. Perlakuan dalam penelitian ini adalah perlakuan perendaman dalam ekstrak kulit Manggis dengan konsentrasi 3, 4, 5 dan 6\%, perlakuan lama perendaman 15 menit dan 30 menit. Tujuan penelitian ini adalah melihat pengaruh tingkat kesukaan konsumen terhadap ikan cakalang (Katsuwonus pelamis L.) asap, yang direndam dalam ekstrak kulit Manggis. Hasil Penelitian ini diharapkan dapat memberikan informasi tentang kajian Tingkat kesukaan konsumen terhadap ikan cakalang asap yang direndam dalam ekstrak kulit Manggis. Penelitian dilaksanakan di Laboratorium Teknologi penanganan dan Pengolahan hasil Perikanan, Fakultas Perikanan dan Ilmu Kelautan, Universitas Sam Ratulangi, selama kurang lebih tiga bulan. Data hasil pengamatan nilai organoleptik untuk kenampakan ikan asap yang direndam dalam ekstrak kulit Manggis adalah 64,5 yang ditemukan pada konsentrasi 5\% dengan lama perendaman 30 menit. Data hasil pengamatan uji organoleptik untuk bau memiliki nilai Total tertinggi 65 Pada Konsentrasi 5\% dengan lama perendaman 30 menit. Data uji organoleptik untuk rasa total terendah 35,5 pada konsentrasi 3\% dengan lama perendaman 15 menit. Data uji organoleptik untuk tekstur terdapat pada konsentrasi $4 \%$, dengan lama perendaman 15 menit. Data hasil penelitian menunjukkan bahwa nilai kadar air dan $\mathrm{pH}$ pada sampel ikan asap yang direndam dalam ekstrak kulit Manggis terlihat stabil nilainya.
\end{abstract}

Kata Kunci: Cakalang, Ikan Asap, Manggis, Gracinia mangostana Linn, Kesukaan Konsumen.

\section{PENDAHULUAN}

Ikan merupakan salah satu bahan makanan yang tidak asing lagi bagi masyarakat Indonesia. Bahan makanan ini memiliki kelebihan yaitu mengandung asam amino esensial yang diperlukan oleh tubuh, disamping nilai biologisnya mencapai $90 \%$ dengan jaringan pengikat sedikit sehingga mudah dicerna, selain itu harganya jauh lebih murah dibandingkan sumber protein lainnya (Adawyah, 2007).

Salah satu jenis pengolahan yang dapat digunakan untuk menghambat proses pembusukan adalah pengasapan ikan, selain bertujuan memberikan manfaat untuk mengawetkan ikan pengolahan ikan dengan cara pengasapan juga memberi aroma yang sedap, warna kecoklatan atau kehitaman, tekstur yang bagus serta cita rasa yang khas dan lezat pada daging ikan yang diolah (Murniati, 2000).

Metode pengasapan yang sering dilakukan oleh masyarakat adalah pengasapan panas yaitu pengasapan dengan menggunakan suhu tinggi mencapai $100^{\circ} \mathrm{C}$ bahkan $120^{\circ} \mathrm{C}$ dengan cara meletakkan ikan yang akan diasapi langsung di atas sumber panas, sehingga kontak langsung antara partikel asap dan ikan sangat besar (Wibowo, 1996).

Manggis (Garcinia mangostana L.) merupakan salah satu tanaman buah asli dari Indonesia yang mudah tumbuh di daerah tropis. Buah ini banyak digemari baik dalam maupun luar negeri karena rasanya yang manis, segar dan berair serta mempunyai kandungan dan komposisi gizi yang sangat dibutuhkan oleh tubuh (Wijaya, $d k k, 2009$ ).

Kulit buah Manggis yang dibuang atau sebagai limbah, ternyata dapat dikembangkan sebagai kandidat obat (Nugroho, 2015). Ini juga berdampak positif pada lingkungan sekitar kita. Dulunya kulit Manggis hanya dibuang dan menjadi sampah, sekarang dapat digunakan sebagai pewarna alami untuk bahan pangan. Pada artikel kali ini akan disajikan mengenai pemanfaatan kulit buah Manggis dalam upaya penemuan zat pewarna alami untuk bahan 
pangan yang dikhususkan untuk ikan cakalang asap.

Berdasarkan pernyataan di atas maka pentingnya penggunaan limbah kulit buah Manggis sebagai bahan dasar untuk memberikan warna yang khas untuk produk ikan cakalang asap. Adanya kelebihan kulit buah Manggis memiliki warna, aroma, rasa yang khas sehingga dapat bermanfaat pada proses pengolahan dimana dapat menjadi solusi dalam memperpertahankan mutu ikan asap.

\section{METODOLOGI PENELITIAN}

\section{Tujuan Penelitian}

Tujuan penelitian ini adalah mempelajari dan menganalisa pengaruh tingkat kesukaan konsumen terhadap ikan cakalang asap yang direndam dalam ekstrak kulit Manggis.

\section{Manfaat Penelitian}

Hasil Penelitian ini diharapkan dapat memberikan informasi kepada kelompok pengolah ikan asap tradisional tentang pewarna alami dan kajian tingkat kesukaan konsumen terhadap ikan cakalang asap yang direndam dalam ekstrak kulit Manggis.

\section{Tempat dan waktu pelaksanaan}

Penelitian tentang tingkat kesukaan konsumen terhadap ikan cakalang asap yang direndam dalam ekstrak kulit Manggis, telah dilaksanakan di Laboratorium Teknologi Penanganan dan Pengolahan Hasil Perikanan Fakultas Perikanan Dan Ilmu Kelautan Universitas Sam Ratulangi, dari bulan Agustus sampai Oktober, tahun 2016.

\section{Alat dan Bahan Penelitian}

Sampel yang digunakan adalah ikan cakalang yang diambil dari Pasar Bersehati dan kulit Manggis dikirim langsung dari Kabupaten Talaud.

Peralatan yang digunakan adalah: blender, penyaring, dan timbangan. Alat yang digunakan dalam uji $\mathrm{pH}$ adalah mortar, timbangan analitik, baker glass, akuades dan larutan buffer. Alat untuk uji kadar air adalah mortar dan pastle, cawan porselen, oven, desikator dan timbangan analitik. Alat untuk uji organoleptik adalah bilik pencicip, contoh uji, dan lembar penilaian (score sheet).

Metode yang digunakan dalam penelitian ini merupakan metode deskriptif.
Penelitian ini menggunakan Rancangan Acak Lengkap (RAL), yang disusun secara faktorial $3 \times 2$ dengan 2 kali ulangan.

\section{HASIL DAN PEMBAHASAN}

\section{Kenampakan}

Data hasil pengamatan nilai organoleptik dapat dilihat bahwa nilai total tertinggi organoleptik uji hedonik untuk kenampakan ikan asap yang direndam dalam ekstrak kulit manggis adalah 64,5 yang terdapat pada konsentrasi $5 \%\left(\mathrm{~A}_{3} \mathrm{~B}_{2}\right)$.

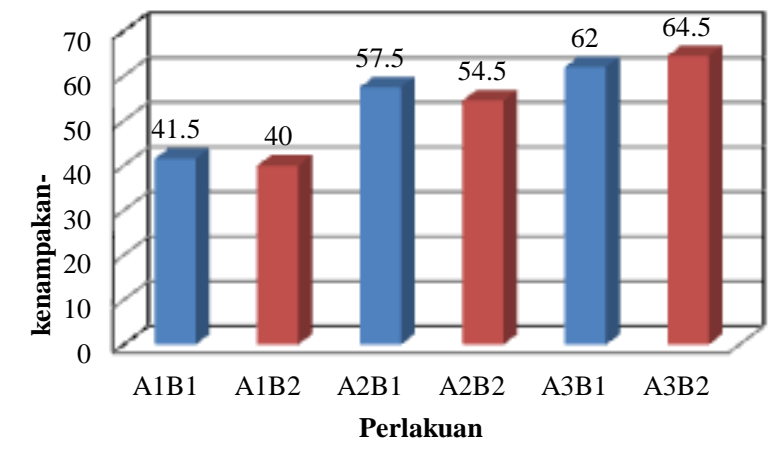

Gambar 1. Hasil organoleptik kenampakan pada ikan cakalang (Katsuwonus pelamis L.) asap yang direndam dalam ekstrak kulit manggis.

Keterangan:

lama perendaman 15 menit

lama perendaman 30 menit

$\mathrm{A}_{1} \mathrm{~B}_{1}=$ lama perendaman 15 menit (konsentrasi 3\%)

$\mathrm{A}_{1} \mathrm{~B}_{2}=$ lama perendaman 30 menit (konsentrasi $3 \%$ )

$\mathrm{A}_{2} \mathrm{~B}_{1}=$ lama perendaman 15 menit (konsentrasi 4\%)

$\mathrm{A}_{2} \mathrm{~B}_{2}=$ lama perendaman 30 menit (konsentrasi 4\%)

$\mathrm{A}_{3} \mathrm{~B}_{1}=$ lama perendaman 15 menit (konsentrasi $5 \%$ )

$\mathrm{A}_{3} \mathrm{~B}_{2}=$ lama perendaman 30 menit (konsentrasi $5 \%$ )

Hasil Uji fridman test menunjukan adanya perbedaan yang nyata $(\mathrm{P} \leq 0,05)$ untuk setiap perlakuan terhadap tingkat kesukaan kenampakan masing-masing produk. Karena adanya perbedaan yang nyata dari tiap perlakuan, maka dilakukan uji lanjut dengan Multiple Comparison Test terhadap produk. Dari hasil uji ini, dapat diketahui bahwa tidak ada perbedaan antara perlakuan yang satu dengan yang lainya.

\section{Bau}

Data hasil pengamatan uji fridman test organoleptik untuk bau pada ikan cakalang asap yang direndam dalam ekstrak kulit buah manggis memiliki nilai Total tertinggi 65 yang didapat pada konsentrasi 5\%. Sedangkan nilai Total terendah 42 di dapat pada konsentrasi 3\% dengan lama perendaman 30 menit. 


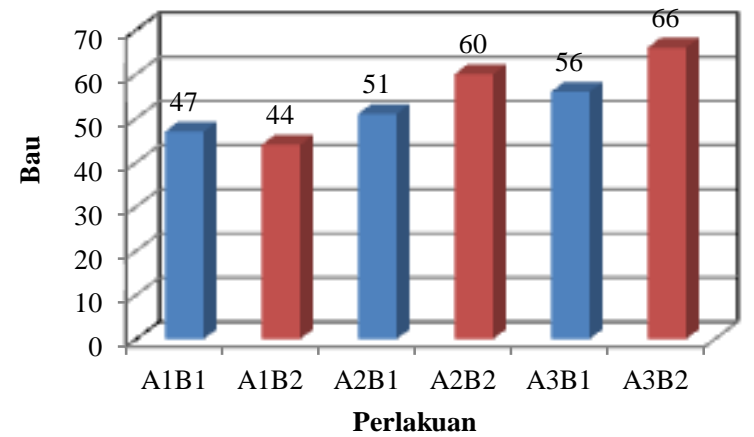

Gambar 2. Hasil Dari uji Fridman Test Keterangan:

\section{$\square \quad$ lama perendaman 15 menit}

lama perendaman 30 menit

$\mathrm{A}_{1} \mathrm{~B}_{1}=$ lama perendaman 15 menit (konsentrasi 3\%)

$\mathrm{A}_{1} \mathrm{~B}_{2}=$ lama perendaman 30 menit (konsentrasi 3\%)

$\mathrm{A}_{2} \mathrm{~B}_{1}=$ lama perendaman 15 menit (konsentrasi $4 \%$ )

$\mathrm{A}_{2} \mathrm{~B}_{2}=$ lama perendaman 30 menit (konsentrasi 4\%)

$\mathrm{A}_{3} \mathrm{~B}_{1}=$ lama perendaman 15 menit (konsentrasi 5\%)

$A_{3} B_{2}=$ lama perendaman 30 menit (konsentrasi 5\%)

Hasil Uji fridman test menunjukan adanya perbedaan yang nyata $(\mathrm{P} \leq 0,05)$ untuk setiap perlakuan terhadap tingkat kesukaan bau masing-masing produk. Karena adanya perbedaan yang nyata dari tiap perlakuan, maka dilakukan uji lanjut dengan Multiple Comparison Test terhadap produk. Dari hasil uji ini, dapat diketahui bahwa tidak ada perbedaan antara perlakuan yang satu dengan yang lainya.

\section{Rasa}

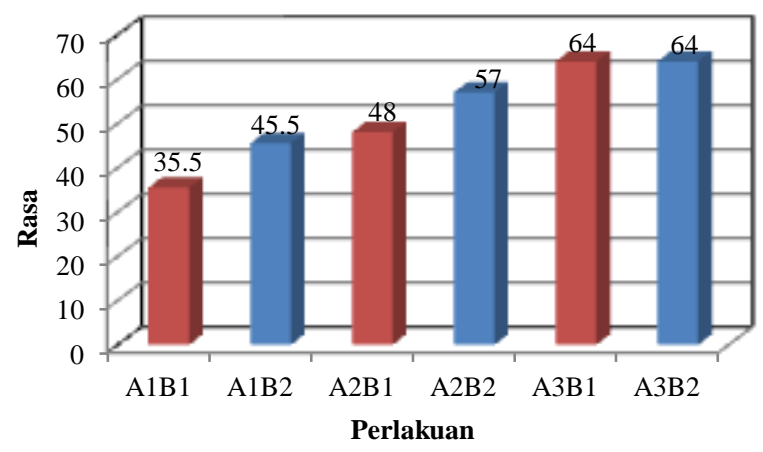

Gambar 3. Hasil nilai untuk rasa dari hasil uji fridman test.

Keterangan:

$\square \quad$ lama perendaman 15 menit
$\square \quad$ lama perendaman 30 menit
$\mathrm{A}_{1} \mathrm{~B}_{1}=$ lama perendaman 15 menit (konsentrasi $\left.3 \%\right)$
$\mathrm{A}_{1} \mathrm{~B}_{2}=$ lama perendaman 30 menit (konsentrasi $\left.3 \%\right)$
$\mathrm{A}_{2} \mathrm{~B}_{1}=$ lama perendaman 15 menit (konsentrasi $\left.4 \%\right)$
$\mathrm{A}_{2} \mathrm{~B}_{2}=$ lama perendaman 30 menit $($ konsentrasi $4 \%)$
$\mathrm{A}_{3} \mathrm{~B}_{1}=$ lama perendaman 15 menit (konsentrasi $\left.5 \%\right)$
$\mathrm{A}_{3} \mathrm{~B}_{2}=$ lama perendaman 30 menit (konsentrasi $\left.5 \%\right)$

Data uji fridman test organoleptik untuk rasa dapat dilihat bahwa nilai total terendah
35,5 terdapat pada konsentrasi 3\%. Sedangkan nilai total tertinggi 64 pada (konsentrasi 5\%). Hasil analisis uji organoleptik untuk rasa pada ikan cakalang asap yang direndam dalam ekstrak kulit manggis dapat dilihat pada Gambar 3.

Hasil Uji fridman test menunjukan adanya perbedaan yang nyata $(\mathrm{P} \leq 0,05)$ untuk setiap perlakuan terhadap tingkat kesukaan rasa masing-masing produk. Karena adanya perbedaan yang nyata dari tiap perlakuan, maka dilakukan uji lanjut dengan Multiple Comparison Test terhadap produk. Dari hasil uji ini, dapat diketahui bahwa tidak ada perbedaan antara perlakuan yang satu dengan yang lainya.

\section{Tekstur}

Data uji fridman test organoleptik untuk tekstur dapat dilihat pada gambar berikut yaitu nilai total terendah terdapat pada konsentrasi $3 \%$. Sedangkan nilai total tertinggi terdapat pada konsentrasi 5\%. Hasil analisis uji organoleptik untuk tekstur pada ikan cakalang asap yang direndam dalam ekstrak kulit manggis dapat di lihat pada Gambar 4.

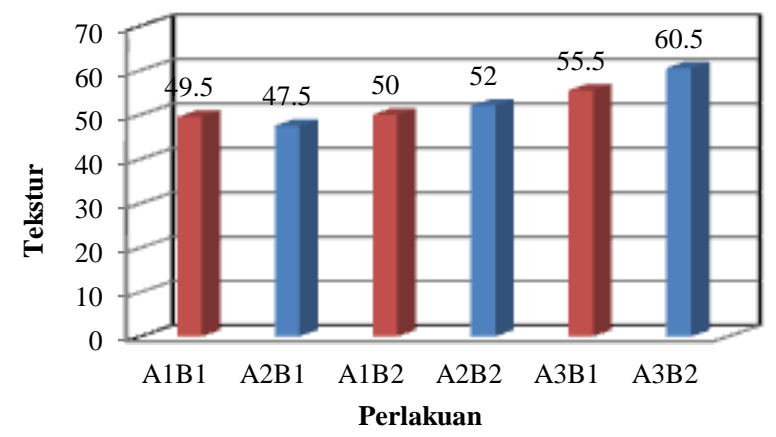

Gambar 4. Hasil nilai untuk tekstur dari hasil uji Fridman test.

Keterangan:

$\square \quad$ lama perendaman 15 menit

lama perendaman 30 menit

$\mathrm{A}_{1} \mathrm{~B}_{1}=$ lama perendaman 15 menit (konsentrasi 3\%)

$\mathrm{A}_{1} \mathrm{~B}_{2}=$ lama perendaman 30 menit (konsentrasi 3\%)

$\mathrm{A}_{2} \mathrm{~B}_{1}=$ lama perendaman 15 menit (konsentrasi 4\%)

$\mathrm{A}_{2} \mathrm{~B}_{2}=$ lama perendaman 30 menit (konsentrasi 4\%)

$\mathrm{A}_{3} \mathrm{~B}_{1}=$ lama perendaman 15 menit (konsentrasi 5\%)

$\mathrm{A}_{3} \mathrm{~B}_{2}=$ lama perendaman 30 menit (konsentrasi 5\%)

Dari gambar di atas menjelaskan bahwa nilai uji hedonik organoleptik untuk rasa terhadap ikan cakalang asap yang direndam dalam ekstrak kulit manngis memiliki nilai tertinggi kosentrasi 5 dengan rasa enak dan kurang gurih. 


\section{Kadar Air}

Pengaruh lama perendaman yang diberi ekstrak kulit manggis tidak memberikan pengaruh terhadap ikan asap. Histogram nilai rata-rata kadar air ikan cakalang asap yang direndam dalam ekstrak kulit manggis dapat dilihat pada gambar 5 .

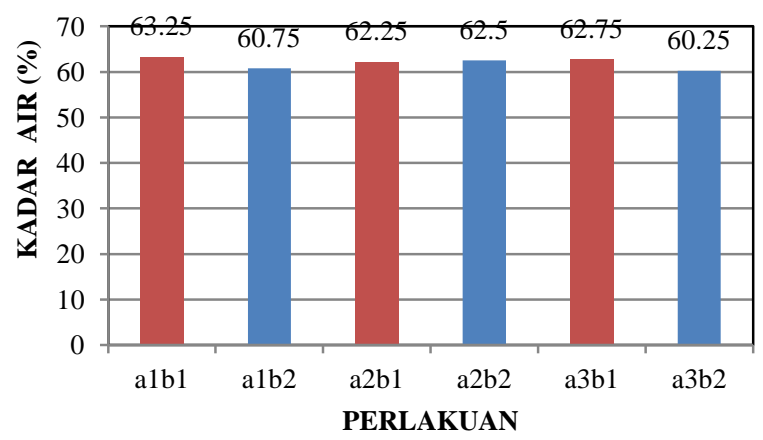

Gambar 5. Hasil rata-rata uji kadar air ikan cakalang (Katsuwonus pelamis L.) asap yang direndam dalam ekstrak kulit manggis.

Keterangan:

lama perendaman 15 menit

lama perendaman 30 menit

$\mathrm{A}_{1} \mathrm{~B}_{1}=$ lama perendaman 15 menit (konsentrasi 3\%)

$\mathrm{A}_{1} \mathrm{~B}_{2}=$ lama perendaman 30 menit (konsentrasi 3\%)

$\mathrm{A}_{2} \mathrm{~B}_{1}=$ lama perendaman 15 menit (konsentrasi 4\%)

$\mathrm{A}_{2} \mathrm{~B}_{2}=$ lama perendaman 30 menit (konsentrasi 4\%)

$\mathrm{A}_{3} \mathrm{~B}_{1}=$ lama perendaman 15 menit (konsentrasi 5\%)

$\mathrm{A}_{3} \mathrm{~B}_{2}=$ lama perendaman 30 menit (konsentrasi 5\%)

Data hasil penelitian menunjukan bahwa kadar air sampel ikan cakalang asap yang direndam dengan ekstrak kulit manggis untuk nilai tertingg terdapat pada konsentyrasi 3\% dan sebaliknya untuk nilai terendah terdapat pada konsentrasi 5\%. Desrtoiser (1998) menyatakan bahwa proses pengeringan didasari atas terjadinya penguapan air oleh udara sebagai akibat perbedaan kandungan uap air antara udara dan produk yang dikeringkan.

\section{Penentuan pH}

Pengaruh lama perendaman yang diberi ekstrak kulit manggis tidak memberikan pengaruh terhadap $\mathrm{pH}$ ikan asap. Histogram nilai rata-rata $\mathrm{pH}$ ikan cakalang asap yang direndam dalam ekstrak kulit manggis dapat dilihat pada gambar 6 .

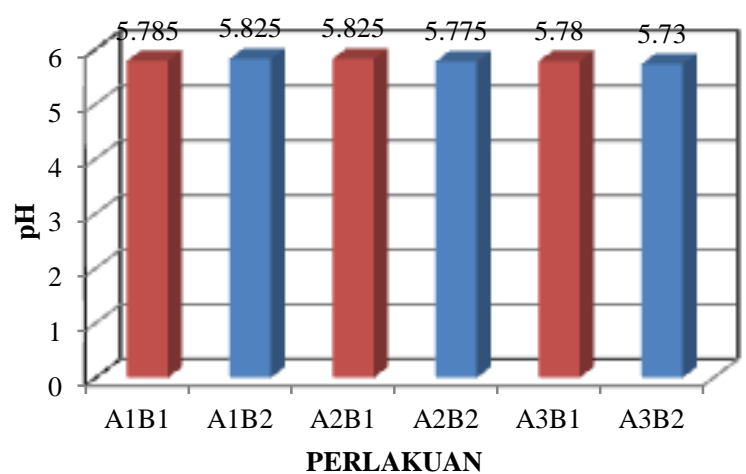

Gambar 6. Hasil rata-rata uji pH ikan cakalng (Katsuwonus pelamis L.) asap yang direndam dakam ekstrak kulit manggis.

Keterangan:

lama perendaman 15 menit

lama perendaman 30 menit

$\mathrm{A}_{1} \mathrm{~B}_{1}=$ lama perendaman 15 menit (konsentrasi 3\%)

$\mathrm{A}_{1} \mathrm{~B}_{2}=$ lama perendaman 30 menit (konsentrasi $3 \%$ )

$\mathrm{A}_{2} \mathrm{~B}_{1}=$ lama perendaman 15 menit (konsentrasi $4 \%$ )

$\mathrm{A}_{2} \mathrm{~B}_{2}=$ lama perendaman 30 menit (konsentrasi 4\%)

$\mathrm{A}_{3} \mathrm{~B}_{1}=$ lama perendaman 15 menit (konsentrasi 5\%)

$\mathrm{A}_{3} \mathrm{~B}_{2}=$ lama perendaman 30 menit (konsentrasi $5 \%$ )

\section{KESIMPULAN DAN SARAN}

\section{Kesimpulan}

Berdasarkan hasil penelitian data hasil uji fridman test nilai organoleptik, untuk kenampakan ikan asap yang diberi ekstrak kulit manggis adalah 64,5 yang ditemukan pada konsentrasi $5 \%$. Perendaman ikan yang berdasarkan data analisa kenampakan, perlakuan pada ikan cakalang asap (Katsuwonus pelamis L.) yang direndam dalam ekstrak kulit manggis memberikan warna yang menarik.

Sedangkan data hasil penelitian menunjukan bahwa kadar air dan $\mathrm{pH}$ sampel ikan asap yang direndam dengan ekstrak kulit manggis tidak memberikan pengaruh terhadap $\mathrm{pH}$ dan kadar air ikan asap.

\section{Saran}

Dari hasil penelitian ini, maka ikan cakalang (Kasuwonus pelamis L.) asap yang direndam dalam ekstrak kulit manggis memberikan pengaruh warna untuk kenampakan dan dapat dipakai oleh masyarakat khususnya kelompok pongolah ikan asap tradisional sebagai pewarna alami dalam produk ikan asap.

\section{DAFTAR PUSTAKA}

Adawyah, Rabiatul. 2007. Pengolahan dan Pengawetan Ikan. Bumi Aksara. Jakarta.

A. S Dan Sunarman. 2000. Pendinginan, Pembekuan Dan Pengawetan Ikan. Penerbit Kanisius. Yogyakarta. 
Nugroho, Agung Endro, 2007. Manggis (Garcinia mangostana L.):Dari Kulit Buah yang Terbuang. Toksikologi, Bagian Farmakologi dan Farmasi Klinik, Fakultas Farmasi, Universitas Gajah Mada, Yogyakarta.

Wibowo, S. 1996. Industri Pengasapan Ikan. Penebar Swadaya. Jakarta
Wijaya, L.A., Marcel P.S., Fenny S. 2009. "Mikroenkapsulasi Antosianin Sebagai Pewarna Alami Sumber Antioksidan Berbasis Limbah Kulit Manggis (Garnicia mangostana L.)". Institut Pertanian Bogor. Bogor. 